Aleksandra Gliniewicz, Anna Zielińska, Katarzyna Kwiatkowska, Dorota Dudek-Godeau, Magdalena Bielska-Lasota

\title{
SURVIVAL IN WOMEN DIAGNOSED WITH BREAST AND CERVICAL CANCER IN POLAND - COMPARED TO EUROPEAN COUNTRIES, BASED ON CONCORD-3 PROGRAMME
}

\author{
WYLECZALNOŚĆ KOBIET Z ROZPOZNANIEM RAKA PIERSI I SZYJKI MACICY \\ W POLSCE NA TLE KRAJÓW EUROPEJSKICH, \\ NA PODSTAWIE BADANIA CONCORD-3
}

\author{
National Institute of Public Health-National Institute of Hygiene in Warsaw \\ Department of Health Promotion and Chronic Diseases Prevention \\ Narodowy Instytut Zdrowia Publicznego - Państwowy Zakład Higieny w Warszawie \\ Zakład Promocji Zdrowia i Prewencji Chorób Przewlekłych
}

\begin{abstract}
INTRODUCTION. The 5-year population-based survival rate, next to cancer incidence and mortality, is a key element for the assessment of effective health care quality provided by OECD in order to establish the condition of health care and set up health care policies. They also apply when assessing breast and cervical cancer prevention in Poland.

AIM. The aim of the paper was to analyse the breast and cervical cancer survival in women in Poland in 20102014 and its changes in 2000-2014 in comparison to other European countries.

RESULTS. The analysis of the 5-year survival rate was performed with the CONCORD-3 programme data. In order to guarantee the comparability of results, the uniform standards for data quality control, all calculations and analyses were performed by a world-leading centre for research, The London School of Hygiene and Tropical Medicine. The absolute value of the survival rate was used to assess survival variations in 2000-2004 and 2010-2014.

In 2010-2014 the highest 5-year survival rate in women with breast cancer was in Island (89\%), Sweden (89\%), Finland (89\%) and Norway (88\%). Despite its systematic improvement, the 5-year survival rate in Poland was lower than in the majority of European countries, and in the final period amounted to 76,6\%. In 2010-2014 the highest survival in women with cervical cancer in Europe was in Island (80\%), Norway (73\%) and Switzerland (71\%). The progress of favourable changes in Poland was not sufficient enough to allow the survival rate $(55 \%)$ to be significantly closer to the European average.

CONCLUSIONS. The 5-year survival rate for breast and cervical cancer in Poland in 2010-2014 was significantly different than in other European countries, and placed Poland among the countries with the lowest survival rate. In 2000-2014 in Poland there was an insignificant progress in survival in women with breast and cervical cancer, which did not contribute to fighting the substantial differences when compared to other European countries.
\end{abstract}

Key words: breast cancer, cervical cancer, 5-year survival rate, European countries, Poland, survival

\section{STRESZCZENIE}

WSTĘP. Wskaźnik 5-letnich przeżyć populacyjnych, obok zachorowalności i umieralności jest kluczowym elementem oceny efektywności systemu opieki zdrowotnej zaproponowanej przez $O E C D$ do określenia stanu zdrowia i kierunków polityki zdrowotnej. Mają one zastosowanie także w Polsce w ocenie zwalczania raka piersi i szyjki macicy.

CEL. Celem pracy była analiza wskaźnika przeżyć kobiet chorych na raka piersi i szyjki macicy w latach 20102014 oraz jego zmian w latach 2000-2014 w Polsce w porównaniu do krajów europejskich.

MATERIAŁ I METODY. Analiza wskaźnika 5-letnich przeżyć została wykonana w oparciu o dane zgromadzone i opracowane w ramach projektu CONCORD-3. Jednorodna metodologia kontroli jakości danych oraz 
obliczenia i analizy zostały przeprowadzone przez jedno centrum analityczne (The London School of Hygiene and Tropical Medicine), co gwarantuje porównywalność wyników.

Zmiany wyleczalności oceniono na podstawie bezwzględnej różnicy wartości wskaźnika w latach 2000-2004 i 2010-2014.

WYNIKI. W latach 2010-2014 najwyższe wartości wskaźnika 5-letnich przeżyć kobiet chorych na raka piersi były w Islandii (89\%), Szwecji (89\%), Finlandii (89\%) i Norwegii (88\%).W Polsce, mimo systematycznej poprawy, wartość wskaźnika pozostawała poniżej większości krajów europejskich i w ostatnim okresie wynosiła 77\%. W Europie w latach 2010-2014 najwyższe wartości wskaźnika wyleczalności kobiet chorych na raka szyjki macicy były w Islandii (80\%), Norwegii (73\%) i Szwajcarii (71\%). W Polsce tempo korzystnych zmian nie było wystarczające, aby wskaźnik przeżyć (55\%) znacząco zbliżył się do przeciętnych w krajach europejskich.

WNIOSKI. W Polsce wskaźniki 5-letnich przeżyć chorych na raka piersi i raka szyjki macicy w latach 20102014 znacząco odbiegały od tych w krajach Europy Zachodniej i plasowały Polskę wśród krajów o najniższych przeżyciach w Europie.

W Polsce w latach 2000-2014 zmiana wskaźnika przeżyć kobiet chorych na raka piersi i szyjki macicy była niewielka i nie wpłynęła na zniwelowanie istniejących znacznych różnic w stosunku do państw Europy.

Slowa kluczowe: rak piersi, rak szyjki macicy, wskaźnik 5-letnich przeżyć, kraje europejskie, Polska, wyleczalność.

\section{INTRODUCTION}

The 5-year population-based survival rate, estimated from the global CONCORD programme is, next to cancer incidence and mortality rate, a key element for the assessment of both a nation's health condition and health care quality. The rate is useful to develop health care policies in European countries (1). These rates, together with the ones used to control the screening effectiveness measured the cancer incidence provided by the Organisation for Economic Co-operation and Development-OECD (1).

A uniform testing standard for the CONCORD programme allows for comparison between regions and countries all over the world as well as for monitoring the changes in time.

CONCORD-2 programme results for 1995-2009 showed that curability for some cancers improved in Poland.

In 2018 the results of the third cycle of the CONCORD programme (2000-2014) were published (3). The data came from 322 population-based cancer registries from 71 countries.

Data from The National Cancer Registry (KRN) and 16 Voivodship Cancer Registries, checked for their quality, were included into the global data system.

According to The National Cancer Registry (4) the number of breast cancer incidence in Poland was systematically higher and in 2014 amounted to 17 379 cases whereas the cervical cancer incidence was systematically lower and amounted to 2807 cases in 2014. Since 2010 the breast cancer mortality was higher and amounted to 5975 cases in 2014. Since 2000 the cervical cancer mortality systematically and slowly decreased and amounted to 1628 cases in 2014. Breast cancer constituted $22 \%$ and cervical

\section{WSTĘP}

Wskaźnik 5-letnich przeżyć populacyjnych obliczany w ramach światowego projektu CONCORD, obok wskaźnika zachorowalności i umieralności jest kluczowym elementem oceny stanu zdrowia społeczeństwa oraz efektywności systemu opieki zdrowotnej. Jest on pomocny do określenia kierunków rozwoju polityki zdrowotnej w krajach europejskich (1). Wskaźniki te, wraz z innymi charakteryzującymi m.in. sprawność skriningów znalazły zastosowanie jako miernik w pomiarze umieralności na raka, zaproponowanym przez Organizację Współpracy Gospodarczej i Rozwoju (ang. Organization for Economic Co-operation and Development - OECD) (1).

Jednorodny standard prowadzenia badań projektu CONCORD umożliwia porównania pomiędzy regionami i krajami na świecie, a także monitorowanie jego zmian w czasie.

Wyniki CONCORD-2 obejmujące lata 1995-2009 wykazały m.in., że w Polsce wyleczalność chorych na niektóre choroby nowotworowe poprawiła się.

W roku 2018 zostały opublikowane wyniki trzeciej edycji projektu CONCORD obejmującego lata 2000-2014 (3). Zgromadzone dane pochodziły z 322 populacyjnych rejestrów nowotworów z 71 krajów świata.

Dane z Polski zgromadzone przez Krajowy Rejestr Nowotworów (KRN) oraz 16 Wojewódzkich Biur Rejestracji Nowotworów, po sprawdzeniu jakości, zasiliły światową bazę danych.

Wg danych KRN (4) w Polsce od 2000 r. liczba zachorowań kobiet na raka piersi systematycznie rosła i w 2014 r. wyniosła 17 379. Z kolei liczba zachorowań na raka szyjki macicy systematycznie malała i w $2014 \mathrm{r}$. wynosiła 2807 . Liczba zgonów z powodu raka piersi 
cancer $3.5 \%$ of cases of women diagnosed with all cancers in Poland in 2014. Breast cancer amounted to $14 \%$ and cervical cancer to almost $4 \%$ in cancer mortality (4).

\section{AIM}

The aim of the paper was to analyse the 5-year survival rate for women with breast and cervical cancer and its changes in 2000-2014 in Poland in comparison to other European countries.

\section{MATERIALS AND METHODS}

The paper presents the 5-year survival rate in women with breast and cervical cancer and its changes during 2000-2014 in European countries, with the special attention given to Poland. The analysis results for the 5-year population-based survival rate are discussed in accordance with ICD-O-3: breast cancer (C50), cervical cancer (C53). The analysis of the 5-year survival rate was performed with the CONCORD-3 programme data (3). In order to guarantee the comparability of the results, uniform standards for data quality control, calculations and analyses were performed by a world-leading centre for research, The London School of Hygiene and Tropical Medicine. The absolute value of the survival indicator was used to assess the survival rate variations in years 2000-2004 and 2010-2014.

\section{RESULTS}

The 5-year survival rate in women with breast and cervical cancer in 2000-2004 and 2010-2014 in 25 European countries and its changes are presented in Table 1. Figures 1 and 2 present the 5 -year survival rate in Poland in comparison to other European countries, separately for breast cancer and cervical cancer.

\section{Breast cancer}

In 2010-2014 the highest 5-year survival rate in women with breast cancer was in Island (89\%), Sweden $(89 \%)$ and Norway (88\%). (Tab. I). Despite its systematic improvement, the survival rate in Poland remained lower than in the majority of European countries, and was $77 \%$ in 2010-2014. The survival in Poland was better only when compared to Slovakia (76\%) and Lithuania (74\%) (Fig. 1). In 2000-2014 the improvement in the survival was present in almost every European country. In Lithuania it increased to almost 9 percentage points. In Poland the change in the survival rate was 5 percentage points. The smallest change was in France (a decrease of 0.1 percentage point) and Slovakia (0.2 percentage points) (Tab. I). od 2010 r. rosła i w 2014 r. wyniosła 5 975. Od 2000 r. liczba zgonów z powodu raka szyjki macicy powoli i systematycznie malała - w roku 2014 wynosiła ona 1 628. W Polsce w 2014 r. w strukturze zachorowań rak piersi stanowił $22 \%$, a rak szyjki macicy $3,5 \%$ wszystkich chorób nowotworowych, na które chorowały kobiety. W strukturze zgonów rak piersi stanowił prawie $14 \%$, a rak szyjki macicy - ok. 4\% (4).

\section{CEL}

Celem pracy była analiza wskaźnika 5-letnich przeżyć kobiet chorych na raka piersi i szyjki macicy oraz jego zmian w latach 2000-2014, w Polsce w porównaniu do krajów europejskich.

\section{MATERIAŁ I METODY}

W pracy przedstawiono wskaźnik 5-letnich przeżyć u kobiet chorych na raka piersi i szyjki macicy, a także zmiany wskaźnika w latach 2000-2014 w krajach europejskich, ze szczególnym uwzględnieniem Polski. Wyniki analiz 5-letnich przeżyć populacyjnych omówiono według kolejności zgodnej z klasyfikacją ICD-O-3: rak piersi (C50) i rak szyjki macicy (C53).

Analiza wskaźnika 5-letnich przeżyć została wykonana $\mathrm{w}$ oparciu o dane zgromadzone $\mathrm{w}$ ramach projektu CONCORD-3 (3). Jednorodna metodologia kontroli jakości danych oraz obliczenia i analizy zostały przeprowadzone przez jedno centrum analityczne (The London School of Hygiene and Tropical Medicine), co gwarantuje porównywalność wyników.

Zmiany wyleczalności oceniono na podstawie bezwzględnej różnicy wartości wskaźnika w latach 2000-2004 i 2010-2014.

\section{WYNIKI}

Wskaźnik 5-letnich przeżyć kobiet z 25 krajów europejskich, które zachorowały na raka piersi i szyjki macicy w latach 2000-2004 i 2010-2014 oraz jego zmiany zawarto w tabeli 1 . Na rycinach 1 i 2 przedstawiono wskaźnik 5-letnich przeżyć w Polsce na tle innych krajów europejskich, odpowiednio dla chorych na raka piersi i raka szyjki macicy.

\section{Rak piersi}

W latach 2010-2014 najwyższe wartości wskaźnika 5-letnich przeżyć kobiet chorych na raka piersi były w Islandii (89\%), Szwecji (89\%), Finlandii (89\%) i Norwegii $(88 \%)$. (Tab. I). W Polsce mimo systematycznej poprawy wartość wskaźnika pozostawała poniżej większości krajów europejskich i w latach 2010-2014 wynosiła 77\%. Wyleczalność w kraju była lepsza tylko w porównaniu ze Słowacją (76\%) i Litwą (74 \%) (Ryc. 1.). 
Table 1. 5-year population-based survival rate in women with breast and cervical cancer and its changes in 2000-2014 in Europe Tabela 1. Wskaźnik 5-letnich przeżyć kobiet chorych na raka piersi i szyjki macicy oraz jego zmiany w okresie 2000-2014 w Europie

\begin{tabular}{|c|c|c|c|c|c|c|c|c|}
\hline \multirow{3}{*}{ Country } & \multicolumn{4}{|c|}{ Breast (C50) } & \multicolumn{4}{|c|}{ Cervix (C53) } \\
\hline & \multirow{2}{*}{$\begin{array}{c}\begin{array}{c}\text { No. of } \\
\text { cases }\end{array} \\
2000-14\end{array}$} & \multicolumn{2}{|c|}{$\begin{array}{c}\text { The } 5 \text {-year } \\
\text { survival rate }(\%)\end{array}$} & \multirow{2}{*}{$\begin{array}{c}\begin{array}{c}\text { Absolute } \\
\text { difference }\end{array} \\
2000-14\end{array}$} & \multirow{2}{*}{$\begin{array}{c}\begin{array}{c}\text { No. of } \\
\text { cases }\end{array} \\
2000-14\end{array}$} & \multicolumn{2}{|c|}{$\begin{array}{c}\text { The 5-year } \\
\text { survival Rate }(\%)\end{array}$} & \multirow{2}{*}{$\begin{array}{l}\begin{array}{l}\text { Absolute } \\
\text { difference }\end{array} \\
2000-14\end{array}$} \\
\hline & & $2000-04$ & $2010-14$ & & & $2000-04$ & $2010-14$ & \\
\hline Austria & 84350 & 81.7 & 84.8 & 3.1 & 25379 & 65.4 & 63.9 & -1.5 \\
\hline Belgium & 123935 & 84.8 & 86.4 & 1.6 & 36594 & 65.1 & 65.4 & 0.3 \\
\hline Bulgaria & 54830 & 70.9 & 78.3 & 7.4 & 16549 & 49.2 & 54.8 & 5.6 \\
\hline Croatia & 37318 & 73.6 & 78.6 & 5.0 & 12744 & 63.2 & 63.2 & 0.0 \\
\hline Czech Republic & 96254 & 75.7 & 81.4 & 5.7 & 46617 & 60.4 & 61.0 & 0.6 \\
\hline Denmark & 66309 & 80.3 & 86.1 & 5.8 & 5761 & 63.0 & 69.5 & 6.5 \\
\hline Estonia & 8437 & 70.9 & 76.6 & 5.7 & 2879 & 62.3 & 66.5 & 4.2 \\
\hline Finland & 67103 & 86.5 & 88.5 & 2.0 & 15525 & 67.8 & 67.4 & -0.4 \\
\hline France & 83091 & 86.8 & 86.7 & -0.1 & 5199 & 61.7 & 65.0 & 3.3 \\
\hline Germany & 341249 & 83.9 & 86.0 & 2.1 & 61642 & 64.9 & 65.2 & 0.3 \\
\hline Iceland & 2958 & 87.4 & 89.1 & 1.7 & 225 & 81.8 & 80.1 & 5.8 \\
\hline Ireland & 38273 & 77.2 & 82.0 & 4.8 & 33119 & 57.8 & 63.6 & -1.7 \\
\hline Italy & 261171 & 84.2 & 86.0 & 1.8 & 23505 & 67.3 & 66.8 & -0.5 \\
\hline Latvia & 15536 & 79.7 & 82.2 & 2.5 & 3452 & 52.8 & 56.0 & 3.2 \\
\hline Lithuania & 18860 & 64.6 & 73.5 & 8.9 & 11922 & 53.8 & 59.2 & 5.4 \\
\hline Netherlands & 221927 & 83.9 & 86.6 & 2.7 & 10422 & 66.1 & 67.5 & 1.4 \\
\hline Norway & 50315 & 84.7 & 87.7 & 3.0 & 132583 & 70.9 & 73.3 & 2.4 \\
\hline Poland & 223729 & 71.3 & 76.5 & 5.2 & 50277 & 51.6 & 55.1 & 3.5 \\
\hline Portugal & 73407 & 81.6 & 87.6 & 6.0 & 14652 & 60.4 & 66.2 & 5.8 \\
\hline Slovakia & 25793 & 75.3 & 75.5 & 0.2 & 10826 & 61.8 & 60.5 & -1.3 \\
\hline Slovenia & 17138 & 78.7 & 83.5 & 4.8 & 15891 & 67.2 & 65.5 & -1.7 \\
\hline Spain & 62316 & 82.9 & 85.2 & 2.3 & 18471 & 63.6 & 64.5 & 0.9 \\
\hline Sweden & 112791 & 85.6 & 88.8 & 3.2 & 65634 & 66.9 & 68.3 & 1.4 \\
\hline Switzerland & 43418 & 84.4 & 86.2 & 1.8 & 11762 & 63.4 & 71.4 & 8.0 \\
\hline United Kingdom & 760238 & 79.8 & 85.6 & 5.8 & 453392 & 58.9 & 63.8 & 4.9 \\
\hline
\end{tabular}

Źródło: Source: Results evaluated from the CONCORD-3 programme data (3) - Authors' own study; Wyniki opracowane w ramach projektu CONCORD 3 - opracowanie własne (3);

\section{Cervical cancer}

In years 2010-2014 the highest survival rate in women with cervical cancer in Europe was in Island (80\%), Norway (73\%) and Switzerland (71\%) (Tab. I). Poland, next to Bulgaria, had the lowest survival in Europe, which amounted to $55 \%$ (Fig. 2). In most European countries the survival increased (by almost 7 percentage points in Denmark and slightly less in Island and Portugal). In five countries, (Austria, Finland, Ireland, Slovakia and Slovenia) the survival rate decreased by about 2 percentage points. The change in survival in Poland in 2000-2014 was less than 4 percentage points (Tab. I).

\section{DISCUSSION}

The above analysis shows that the survival in women with breast and cervical cancer in 2010-2014 in Europe was diversified despite the survival increase in most European countries. In Poland the survival increase amounted to almost 5 percentage points for patients with breast cancer and almost 4 percentage points for women with cervical cancer.
W latach 2000-2014 poprawa przeżyć była prawie we wszystkich krajach europejskich. Na Litwie poprawa ta sięgała prawie 9 pkt.\%. W Polsce zmiana wskaźnika wyleczalności wynosiła 5 pkt.\% .Najmniejsze zmiany były we Francji (-0,1 pkt.\%) i Na Słowacji $(0,2$ pkt.\%) (Tab. I.)

\section{Rak szyjki macicy}

W Europie w latach 2010-2014 najwyższe wartości wskaźnika wyleczalności kobiet chorych na raka szyjki macicy były w Islandii (80\%), Norwegii (73\%) i Szwajcarii (71\%) (Tab. I.). W Polsce wskaźnik przeżyć, obok Bułgarii należał do najniższych w Europie i wynosił $55 \%$. (Ryc. 2.).

W większości krajów europejskich wartość wskaźnika wzrosła (o prawie 7 pkt.\% w Danii i nieco mniej w Islandii i Portugalii). W pięciu krajach (Austria, Finlandia, Irlandia, Słowacja, Słowenia) wskaźnik obniżył się o ok. 2 pkt.\%. Zmiana wskaźnika przeżyć w Polsce w latach 2000-2014 wynosiła niespełna 4 pkt. \% (Tab. I.) 
Fig. 1. Variations and changes in 5-year survival rate in women with breast cancer in Europe in 2000-2014.

Ryc. 1. Zróżnicowanie oraz zmiany wskaźnika 5-letnich przeżyć kobiet chorych na raka piersi w Europie w latach 2000-2014

Breast (C50)

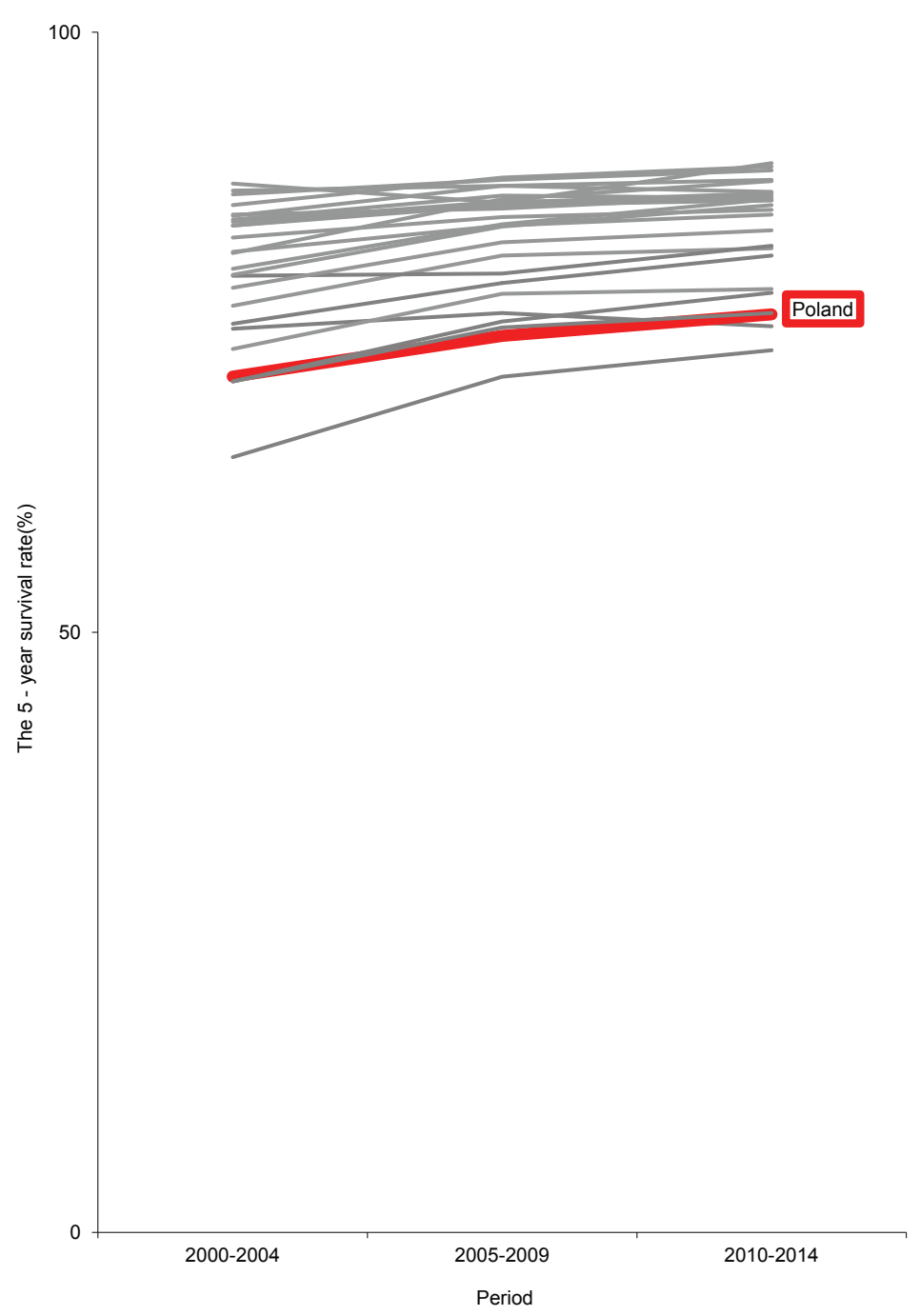

Source: Results evaluated from CONCORD-3 programme data (3) - Authors' own study

Źródło: Wyniki opracowane w ramach projektu CONCORD 3 (3) - opracowanie własne

European countries marked with solid grey line, Poland - solid red line .

Kraje europejskie oznaczono linią ciągłą szarą, Polskę linią ciągłą czerwoną.

That change only slightly contributed to narrowing the gap between Poland and other European countries, and despite those favourable changes the survival in Poland was still among the lowest in Europe.

That survival increase in patients with cervical cancer kept placing Poland on the level similar to Bulgaria and Lithuania, which are the countries with the lowest survivals in Europe. According to the OECD data the number of Polish women covered by the population-based screening amounted to about $72 \%$, which proves a high intensity screening whereas in Lithuania and Bulgaria it did not exceed 34\% (5).

There is a favourable decrease in mortality for patients with cervical cancer both in Poland and most European countries. This trend, however, does not mirror the screening intensity (6).

\section{DYSKUSJA}

Z przedstawionej analizy wynika, że wyleczalność kobiet chorych na raka piersi i raka szyjki macicy w latach 2010-2014 była w Europie zróżnicowana, pomimo wzrostu wartości tego wskaźnika w większości krajów europejskich. W Polsce wzrost wskaźnika wynosił prawie 5 pkt.\% u chorych na raka piersi oraz niespełna 4 pkt.\% u chorych na raka szyjki macicy.

Zmiana ta tylko w niewielkim stopniu przyczyniła się do zmniejszenia dystansu Polski w stosunku do innych krajów europejskich i pomimo tych korzystnych zmian, przeżycia w Polsce nadal należały do najniższych w Europie. 
Fig. 2. Variations and changes in 5-year survival rate in women with cervical cancer in Europe in 2000-2014.

Ryc. 2. Zróżnicowanie oraz zmiany wskaźnika 5-letnich przeżyć kobiet chorych na raka szyjki macicy w Europie w latach 2000-2014

Cervix (C53)

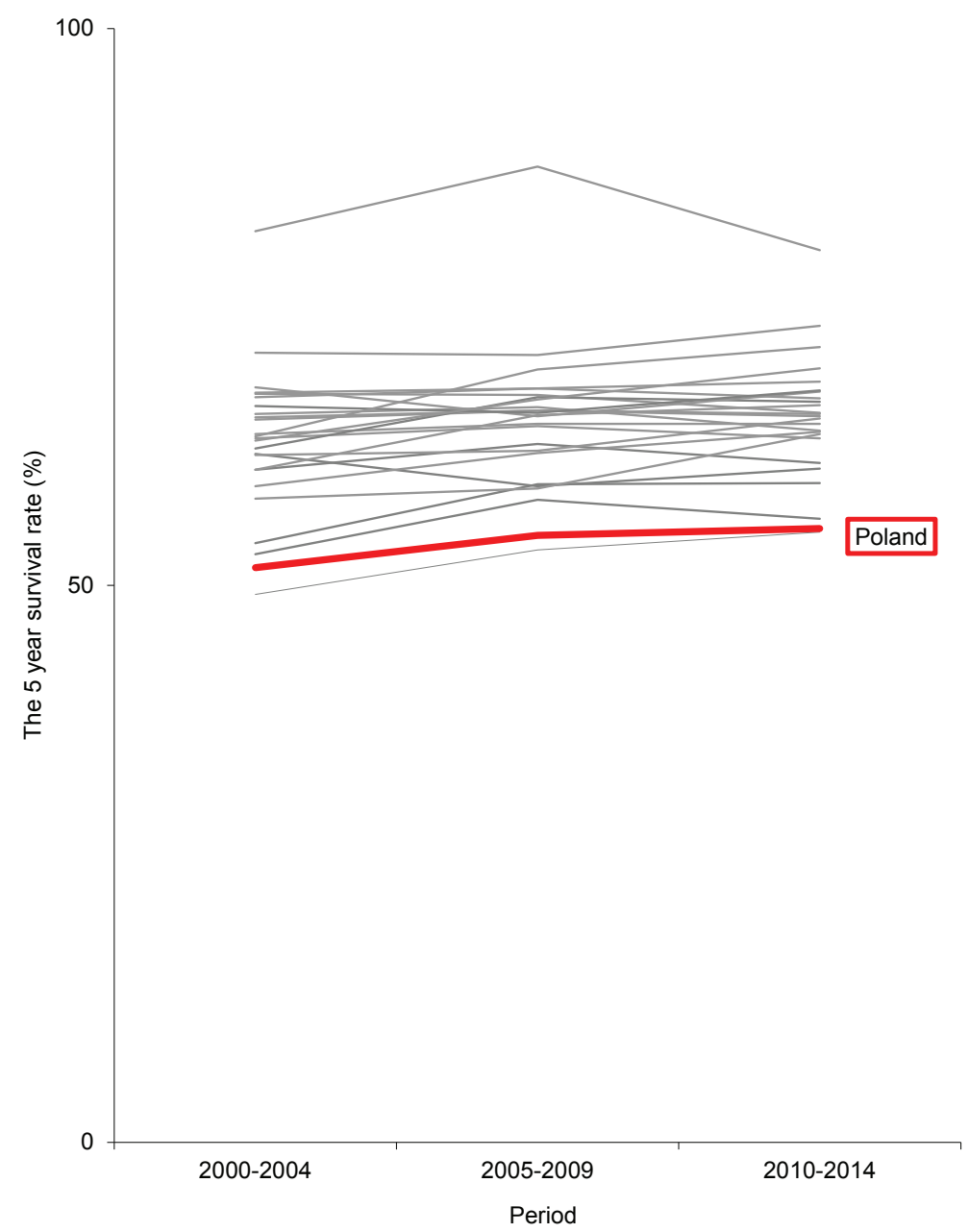

Source: Results evaluated from CONCORD-3 programme data (3) - Authors' own study.

Źródło: Wyniki opracowane w ramach projektu CONCORD-3 (3) - opracowanie własne

European countries marked with solid grey line, Poland - solid red line .

Kraje europejskie oznaczono linią ciągłą szarą, Polskę linią ciągłą czerwoną.

Mortality still remains on a high level when compared to European countries (1). The current, slow trend of decreasing mortality in cervical cancer in Poland seems to be related to a natural trend of lower incidence in this cancer in the country.

Observing these changes one may conclude the population-based screening programme has still not effectively influenced the epidemiological situation in Poland since its introduction in 2006 (1).

It seems that underfunding in health care, including cancer care, might be one of the reasons for slow changes in the survival rates and mortality trends in Poland in comparison to other European countries.

Ginsburg et al. (7) drew attention to the fact that survival in women with breast and cervical cancer is lower in less developed countries and higher in more developed countries. In 2010-2014, apart from
Przedstawiony w pracy wzrost wskaźnika przeżyć chorych na raka szyjki macicy nadal plasował Polskę na poziomie podobnym do Bułgarii i Litwy, tj. krajów, w których przeżycia należą do najniższych w Europie. Według danych OECD odsetek kobiet objętych skriningiem w Polsce wynosił ok. 72\%, co świadczy o wysokiej intensywności skriningu, podczas gdy na Litwie i w Bułgarii nie przekraczał on 34\% (5).

W Polsce u chorych na raka szyjki macicy, podobnie jak i w większości krajów europejskich obserwuje się korzystny trend obniżającej się umieralności. Trend ten nie odzwierciedla intensywności skriningu (6). Umieralność kształtuje się ciągle na wysokim poziomie w porównaniu do krajów europejskich (1). Obecny, powolny trend obniżającej się umieralności na raka szyjki macicy w Polsce wydaje się być związany z naturalnym trendem obniżającej się zachorowalności na ten nowotwór w Polsce. 
Bulgaria, all European countries belonged to very highly developed countries (Human Development Index, HDI - above 0.8). In Poland as well as in Slovakia and Lithuania despite a very high HDI the survival in breast and cervical cancer was lower compared to other European countries. Since there are no cultural constraints on women's access to health care, other conditions must be taken into consideration, among which the financial and organisational ones.

Based on the analysis of survival in patients with all malignant cancers in total in the countries from EUROCARE project, Baili et al. (8) proved a correlation between the 5-year survival rate (age-standardised relative survival), gross national income and health care expenditures. Furthermore, Gatta et al. (9) analysed survival differences in malignant cancers in European countries in relation to their national total health care expenditures. In countries with higher spending such as Island, Sweden, Switzerland and Norway the survival was higher than in countries with less health care expenditures, and where the survival was worse.

According to Eurostat database the national expenditure on health care per capita in Poland in 2014 was 683.66 euros, five times less than in Great Britain and France, and approximately 9 times less than in Sweden (10). In 2014 the health care expenditure in Poland was $4.8 \%$ of GDP, compared to an average $7.3 \%$ in European countries. Only Estonia spent less money on health care from its national budget according to the database. As for the 5-year survival rate in breast and cervical cancer it may be concluded that the survival in breast cancer in Estonia is similar to Poland. However, it is higher by about 11 percentage points in patients with cervical cancer (Tab. I).

A multi-year budget for 2017-2020 (WPFP) was introduced by The Ministry of Finance in April 2017. This financial plan includes a systematic increase in the national health care expenditure up to $6 \%$ of GDP in 2025 (11). Central and Eastern Europe countries which in the 90's underwent political and economic transformation spend today more on health care than Poland (Hungary $-5.1 \%$, Slovakia $-5.6 \%$, the Czech Republic $-6.3 \%$ of GDP (11). Such numbers prove a high financial deficit in the Polish health care. The analysis of cancer health care expenditures showed that in Poland in 2014 it was 42 euros per capita, and belonged to the lowest in Europe. To compare, such expenditure in that time was twice higher in the Czech Republic (85 euros) (12).

Apart from financial reasons, there are also systemic barriers as causes for such a low survival in women's cancers. The Supreme Audit Office report (NIK) (13) points at inappropriate allocation of funding in the cancer care, together with underestimation of medical procedures. Moreover, there are organisational problems such as the lack of health care continuity and quality
W świetle obserwowanych zmian wydaje się, że w okresie począwszy od wdrożenia w roku 2006 skriningu populacyjnego nie wykazał on jeszcze skutecznego wpływu na sytuację epidemiologiczną w kraju (1).

Wydaje się, że jedną z przyczyn powolnych zmian wskaźników wyleczalności i trendów umieralności w Polsce w porównaniu do innych krajów Europy może być niewystarczające finansowanie opieki zdrowotnej, w tym także opieki onkologicznej.

Ginsburg i wsp. (7) zwrócili uwagę, że przeżycia kobiet chorych na raka piersi i szyjki macicy są niższe w krajach słabiej rozwiniętych, a wyższe w krajach wysoko rozwiniętych. W latach 2010-2014 wszystkie kraje europejskie, oprócz Bułgarii należały do bardzo wysoko rozwiniętych (HDI - Human Development Index - Wskaźnik Rozwoju Społeczno-Gospodarczego powyżej 0,8 ). W Polsce, podobnie jak na Słowacji i Litwie mimo bardzo wysokich wartości wskaźnika HDI, wyleczalność chorych na raka piersi i szyjki macicy była niższa $\mathrm{w}$ innych krajach europejskich. Ponieważ nie można mówić tu o uwarunkowaniach kulturowych utrudniających kobietom dostęp do opieki medycznej, istnieją inne przyczyny, wśród nich finansowe i organizacyjne.

Baili i wsp. (8) na podstawie analiz przeżyć u chorych na wszystkie nowotwory złośliwe, ogółem, w krajach uczestniczących w projekcie EUROCARE - 5 wykazali korelację pomiędzy wartością wskaźnika 5-letnich przeżyć (age-standarised relative survival) a dochodem narodowym brutto oraz wydatkami na zdrowie. Również Gatta i wsp. (9) badali zróżnicowanie przeżyć chorych na nowotwory złośliwe w krajach europejskich w zależności od całkowitych narodowych wydatków na ochronę zdrowia. W krajach o wyższych wydatkach tj. Islandii, Szwecji, Szwajcarii, Norwegii przeżycia były wyższe niż w krajach, które wydatkowały mniej na ochronę zdrowia (np. w Polsce, Słowacji, Czechach i na Słowenii), gdzie wyleczalność była gorsza.

Według danych Eurostatu w Polsce w roku 2014 wydatki rządowe na opiekę zdrowotną per capita wynosiły 683,66 EUR, czyli pięciokrotnie mniej niż w Wielkiej Brytanii, Francji oraz ok. 9-krotnie mniej niż w Szwecji (10).

W roku 2014 środki na opiekę zdrowotną w Polsce wynosiły 4,8\% PKB (produktu krajowego brutto), przy średniej w państwach Europy wynoszącej 7,3\%. $\mathrm{Z}$ dostępnych danych wynikało, że mniej pieniędzy z budżetu na zdrowie przeznaczył tylko rząd Estonii - 4,7\% PKB (10). Odnosząc się do 5-letnich przeżyć w przypadku raka piersi i szyjki macicy (Ryc. 1 i 2) można stwierdzić, że w Estonii wskaźnik ten u chorych na raka piersi jest podobny jak w Polsce, ale u chorych na raka szyjki macicy jest wyższy o ok. 11 pkt.\% (Tab. I.) 
control as well as a limited access to optimal treatment methods. In 2016 an average waiting time for urgent CT was 7-49 days, depending on the voivodship; more than half of the health care centres were unable to perform pathology tests due to the lack of pathology departments (13). The Supreme Audit Office concluded that cancer treatment in Poland in 2017 was too decentralised and did not provide patients with a full and complex treatment. More than half of new anti-cancer drugs registered in Europe was unavailable in Poland.

Minicozzi et al. (14) proved that the 5-year survival rate in patients with breast cancer at the same advancement stage is significantly lower in Eastern Europe countries than in other European regions. The authors suggested that a worse survival, especially in patients with the early-stage cancer may result from inefficient treatment, which also applies to populationbased screening patients referred to treatment.

The National Comprehensive Cancer Network project (KSO) currently being implemented in Poland is expected to significantly improve the cancer care. It aims at re-ordering decentralised cancer care; standardising of cancer diagnostics, independently of patients' place of residence; increasing early-stage cancer diagnostics (15).

The National Institute of Public Health - National Institute of Hygiene (NIZP-PZH) joined a European Joint Action - Innovative Partnership for Action Against Cancer project (JA-iPAAC) and performs pilot studies in order to facilitate and improve cancer care, following the European standards, as well as to work on quality indicators, and consequently, to implement them in multidisciplinary cancer care (15). It is expected that the results will strengthen patients' felling of safety and treatment satisfaction and improve the population's epidemiological indicators, including cancer survival.

\section{CONCLUSIONS}

1. 5-year survival rate in patients with breast and cervical cancer in Poland in 2010-2014 significantly differed from Western Europe and placed Poland among countries with the lowest survival in Europe.

2. In 2000-2014 in Poland the change in survival in women with breast and cervical cancer did not contribute to fighting significant differences when compared to majority of European countries.

3. It seems that low survival in cancer patients, including breast and cervical cancer is related to health care underfunding, despite the fact that Human Development Index placed Poland among highly advanced countries.

4. A planned increase in health care budget funding in cancer care ought to be strengthen by ac-
W kwietniu 2017 r. został opublikowany przez Ministerstwo Finansów Wieloletni Plan Finansowy Państwa (WPFP) na lata 2017 - 2020. Zgodnie z tym planem przewidywane jest stopniowe zwiększanie wydatków z budżetu państwa na ochronę zdrowia do wysokości 6\% PKB w roku 2025 (11). W Europie Środkowo-Wschodniej państwa, które przeszły transformację gospodarczą i polityczną w latach 90. XX wieku, na ochronę zdrowia więcej niż Polska wydają: Węgry - 5, 1\% PKB, Słowacja - 5, 6\%, Czechy $-6,3 \%$ (11). Dane te świadczą o dużych deficytach finansowych w ochronie zdrowia w Polsce. Analiza wydatków na opiekę onkologiczną wykazała, że w Polsce w 2014 r. wynosily one 42 EUR per capita i należały do najniższych w Europie - dla porównania w Czechach były one w tym okresie 2 razy wyższe (85 EUR) (12).

U podstaw niskiej wyleczalności na nowotwory kobiece w Polsce oprócz przyczyn finansowych leżą także trudności systemowe. Według raportu Najwyższej Izby Kontroli (NIK) (13) oprócz nieodpowiedniej alokacji środków w opiece onkologicznej i zbyt nisko wycenionych procedur, istnieją problemy organizacyjne, a wśród nich: brak ciągłości opieki lekarskiej, ograniczona dostępność do optymalnych metod leczenia, brak nadzoru nad jakością. Średni czas oczekiwania na tomografię komputerową ze wskazań pilnych w roku 2016 wynosił 7-49 dni w zależności od województwa; ponad połowa jednostek leczniczych nie mogła przeprowadzić kompletnych badań patomorfologicznych z powodu braku zakładu patomorfologii (13). NIK ocenił, że w 2017 r. system leczenia chorób nowotworowych w Polsce był rozproszony i nie zapewniał pacjentom kompleksowego leczenia. Ponad połowa nowoczesnych leków onkologicznych zarejestrowanych w Europie nie była dostępna w Polsce.

Minicozzi i wsp. (14) wykazali, że wskaźnik 5-letnich przeżyć chorych na raka piersi w tym samym stopniu zaawansowania jest znacząco niższy w państwach Europy Wschodniej w porównaniu z innymi regionami Europy. Autorzy ci sugerują, że gorsze przeżycia chorych w szczególności na raka we wczesnym stopniu zaawansowania mogą być wynikiem mało skutecznego leczenia, co dotyczy także uczestniczek skriningu skierowanych na leczenie.

Oczekuje się, że aktualnie wdrażany w Polsce projekt Krajowej Sieci Onkologicznej (KSO) istotnie usprawni system opieki onkologicznej. W ramach KSO planowane jest m.in.: uporządkowanie rozproszonego systemu lecznictwa onkologicznego, ujednolicenie standardów diagnostyki niezależnie od miejsca zamieszkania, zwiększenie wykrywalności nowotworów we wczesnym stopniu zaawansowania (15).

W ramach europejskiego projektu JA-iPAAC (Joint Action - Innovative Partnership for Action Against Cancer) NIZP-PZH realizuje badanie pilotażowe zmierzające do usprawnienia opieki onkologicznej przy zachowaniu standardów europejskich oraz opracowanie wskaźników jej ja- 
tions aiming at improving standards provided in European projects, e.g. Joint Action - Innovative Partnership for Action Against Cancer project.

\section{REFERENCES}

1. OECD/EU (2018), Health at a Glance: Europe 2018: State of Health in the EU Cycle, OECD Publishing, Paris, [Internet] [cited 2018 Oct 03] Available from: https://doi.org/10.1787/health_glance_eur-2018-en

2. Allemani C., Weir HK., Carreira H., et al. Global surveillance of cancer survival 1995-2009: analysis of individual data for 25676887 patients from 279 population-based registries in 67 countries (CONCORD-2), Lancet 2015; 385: 977-1010

3. Allemani, C. Matsuda T., Di Carlo V, et al. Global surveillance of trends in cancer survival 2000-14 (CONCORD-3): Analysis of individual records for 37 513025 patients diagnosed with one of 18 cancers from 322 population-based registries in 71 countries, Lancet 2018, 391 (10125): 1023-1075

4. Krajowy Rejestr Nowotworów, [Internet] [cited 2018 Sep 16 ] Available from: http://onkologia.org.pl/raporty/

5. OECD/EU (2016), Health at a Glance: Europe 2016 - State of Health in the EU Cycle, OECD Publishing, Paris, [Internet] [cited 2018 Sep 15] Available from: http://dx.doi.org/10.1787/9789264265592-en

6. Kwiatkowska $\mathrm{K}$, et al. Wskaźnik 5-letnich przeżyć chorych na nowotwory złośliwe $\mathrm{w}$ Polsce $\mathrm{w}$ latach 2000-2014. Zróżnicowanie między województwami: Wojtyniak B, Goryński P. red. Sytuacja zdrowotna ludności Polski i jej uwarunkowania. Narodowy Instytut Zdrowia Publicznego-PZH 2018; 185-195

7. Ginsburg O., Bray F., Coleman M.P, et al. The global burden of women's cancers: a grand challenge in global health. The Lancet 2017; 389: $847-860$

8. Baili P, Di Salvo F, Marcos-Gragera R, et al. Age and case mix-standardized survival for all cancer patients in Europe 1999-2007: results of EUROCARE-5, a population-based study. Eur. J. Canc 2015; 51:2120-2129

9. Gatta G., Trama A., Capocaccia. R. Variations in cancer survival and Patterns of care across Europe: Roles of Wealth and Health -Care Organization, J Natl Cancer Inst Monogr. 2013;2013(46): 79-87

10. Eurostat. Health care expenditure statistics, [Internet] [cited 2018 Sep 14] Available from: http://appsso.eurostat.ec. europa.eu

11. Ministerstwo Zdrowia. Wieloletni Plan Finansowy, [Internet] [cited 2018 Sep 10] Available from: http:// www.mf.gov.pl/en/ministerstwo finansow/dzialalnosc/ finanse-publiczne/wieloletni-plan-finansowy-panstwa

12. EY Polska. Dostępność innowacyjnych leków onkologicznych w Polsce na tle wybranych krajów Unii Europejskiej oraz Szwajcarii. Raport przygotowany na zlecenie Alivia Fundacji Onkologicznej Osób Młodych, 2015, [Internet] [cited 2018 Sep 05] Available from: https://alivia.org.pl/raport2015

13. Raport Najwyższej Izby Kontroli, Warszawa, 30.01.2018, [Internet] [cited 2018 Sep 09] Available from: http://www.nik.gov.pl kości, a następnie ich wykorzystanie w implementacji sieci wielodyscyplinarnej opieki onkologicznej (16). Oczekuje się, że w efekcie wdrażania proponowanych rozwiązań $\mathrm{w}$ ramach realizowanego projektu będą - w perspektywie pacjenta: poprawa poczucia bezpieczeństwa i satysfakcji $\mathrm{z}$ leczenia, a w perspektywie populacji - poprawa wskaźników epidemiologicznych, w tym wskaźników przeżyć.

\section{WNIOSKI}

1. W Polsce wskaźniki 5-letnich przeżyć chorych na raka piersi i raka szyjki macicy w latach 2010 2014 znacząco odbiegały od tych w krajach Europy Zachodniej i plasowały Polskę wśród krajów o najniższych przeżyciach w Europie

2. W Polsce w latach 2000-2014 zmiana wskaźnika przeżyć kobiet chorych na raka piersi i szyjki macicy nie wpłynęła na zniwelowanie istniejących znacznych różnic $\mathrm{w}$ porównaniu $\mathrm{z}$ większością krajów UE.

3. Wydaje się, że niskie wskaźniki wyleczalności chorych na raka, w tym na raka piersi i raka szyjki macicy uwarunkowane są m.in. niskimi nakładami na opiekę zdrowotną, mimo, że wskaźnik HDI plasuje Polskę wśród krajów wysokorozwiniętych.

4. Planowane zwiększenie środków budżetowych na opiekę zdrowotną w obszarze opieki onkologicznej powinno być wsparte działaniami zmierzającymi do poprawy standardów opracowanych w ramach projektów europejskich, m.in. projekt iPAAC.

14. Minicozzi P, Walsh P., Sanchez M, et al. Is low survival for cancer in Eastern Europe due principally to late stage at diagnosis?. Eur. J. Canc. 2018; 3: $127-137$

15. Koncepcja organizacji i funkcjonowania Krajowej Sieci Onkologicznej, [Internet] [cited 2018 Sep 09] Available from: https://www.gov.pl/zdrowie/koncepcja-organizacji-i-funkcjonowania-krajowej-sieci-onkologicznej

16. Joint Action - Innovative Partnership for Action Against Cancer, [Internet] [cited 2018 Sep 03] Available from: https://www.ipaac.eu/en/work-packages/wp10

Received: 12.10.2018.

Accepted for publication: 11.12.2018

Otrzymano: $12.10 .2018 \mathrm{r}$.

Zaakceptowano do publikacji: 11.12.2018 r.

Address for correspondence:

Adres do korespondencji:

Aleksandra Gliniewicz

Zakład Promocji Zdrowia i Prewencji Chorób Przewlekłych Narodowy Instytut Zdrowia Publicznego - Państwowy Zakład Higieny

ul. Chocimska 24, 00-791 Warszawa

e-mail: agliniewicz@pzh.gov.pl 